\title{
"There has been a Celtic Tiger of fiction": An Interview with Claire Kilroy
}

\author{
Alberto Lozano García \\ University of Granada, Spain
}

Copyright (c) 2018 by Alberto Lozano García. This text may be archived and redistributed both in electronic form and in hard copy, provided that the author and journal are properly cited and no fee is charged for access.

\begin{abstract}
Claire Kilroy attended the "First Intensive Seminar Week on Irish Studies" that Dr Pilar Villar Argáiz organised at the University of Granada (from 15th to 18th of December 2015), where the writer gave a talk about her latest novel, The Devil I Know. The aim of this interview was both to understand how the post-Celtic Tiger social context motivated not only the content of this novel but also its formal features, and to map the correlation between these two aspects. Kilroy also speaks about the political and cultural background of her book, her literary heritage, the creative process behind the composition of this novel, its characterisation devices and narrative structure, and her next writing projects.
\end{abstract}

Key Words. Celtic Tiger Period, Contemporary Irish Literature, Claire Kilroy, Irish Fiction, Post-Celtic Tiger Literature.

Resumen. Claire Kilroy acudió al "Primer Seminario Intensivo sobre Estudios Irlandeses" organizado por la Dra. Pilar Villar Argáiz en la Universidad de Granada (del 15 al 18 de Diciembre de 2015), en el que la escritora irlandesa habló de su última novela, The Devil I Know. El objetivo de esta entrevista se centra en comprender el contenido de la novela así como sus características formales, todo ello originado por el contexto social de Irlanda tras el periodo conocido como Tigre Celta. Se buscará por tanto trazar la correlación entre ambos aspectos en la novela. Kilroy también habla aquí sobre el trasfondo cultural y político de su novela, sobre su herencia literaria, sobre el proceso creativo detrás de esta obra, sus mecanismos de caracterización y de estructura narrativa, y sobre sus próximos proyectos.

Palabras clave. Periodo del Tigre Celta, literatura irlandesa contemporánea, Claire Kilroy, ficción irlandesa, literatura post-Tigre Celta.

Claire Kilroy (Dublin, 1973) is the author of four novels: All Summer (Faber \& Faber, 2003), Tenderwire (Faber \& Faber, 2006), All Names Have Been Changed (Faber \& Faber, 2009) and The Devil I Know (Faber \& Faber, 2012). While her previous novels concentrate on the topic of the arts, The Devil I Know is Claire Kilroy's first book that explicitly reflects on Irish politics. Her novel is a satirical revision of the boom and bust of the property bubble in the Emerald Isle. 
Alberto Lozano García: There is a growing interest in how post-Celtic Tiger literature reflects the social changes that have occurred in the last twenty years. Ireland's boom and bust is the main topic of your novel The Devil I Know. Like other historical events, it seems that the Irish property bubble and its crash have become a distinctive literary topic with its own archetypal characters and themes. Do you agree with this statement? If so, in which sense?

Claire Kilroy: There is a genre now called Austerity fiction, which I've encountered a lot in the universities. I've been in Germany and they are doing Irish Austerity literature and it is all over the US, so yes, it has become a definite genre. The second part of your question: are there archetypal characters and themes? I would say no. Irish literary fiction is always chaotic and personal, so I couldn't pick out archetypal characters yet. There were certainly archetypes in the Celtic Tiger but not in the books.

There was a very strong literary movement during the Celtic Tiger. A lot of Irish writers started writing historical fiction about the Famine or about people having to emigrate to America in the 1950s. They did not write about the Celtic Tiger because it was very hard to capture; it didn't make any sense and it was almost repellent to representation other than as satire. Literary fiction certainly can have satire, but it is deeper, so there was a kind of a gap created during the Celtic Tiger period when historical fiction and commercial fiction - crime and chick lit - came to the fore. So, once the boom collapsed, once the economy crashed, then the stories started coming out because now we have a story: there is a beginning, a middle and an end and writers can start telling that story. It is no longer in flux. So yes, there has been a Celtic Tiger of fiction about it and there are some great novels. It's filtering through to a lot of novels - Anne Enright's The Forgotten Waltz, about homeowners buying and selling, Paul Murray just published The Mark and the Void, about bankers. I just read a really good one by Dermot Bolger called Tanglewood, again about an ordinary Irish person trying to make money on his house. Are there archetypal characters? Not really. Not yet. It's just trying to tell the story in the way it comes to the individual writer. Writers are like cats: you can't get them to do anything. In literary fiction, in whatever way, the imagination tackles the topic. But genre fiction is different - it has a formula which you follow for the audience and the market.

\section{ALG: Would you consider yourself to be part of a current literary generation? In your view, what would be the features that unite this generation?}

CK: That's very tricky. There are writers who are my friends but we write totally different stuff. Do I feel part of a movement? I can't say I do. There is a new generation coming up behind me... Back to the cats' comment: the human imagination is a cat, there is no cohesion; we are all doing our individual thing. There is great camaraderie within it, we are all friends, but I don't read my friends work before they publish it, we don't really talk about our work. Do I see myself in opposition to the generation ahead of me? Absolutely not. James Joyce was actively rebelling, but he was rebelling against our society. My last two books have been angry at Irish society. So I cannot say that there is a movement. There is just collegiality, but we are all doing our own thing and I find my generation's work interesting. I find the older crowd's work interesting. I do find Irish writing interesting, but it is hard to pinpoint a shared imaginative train within it.

ALG: The Devil I Know begins with a quotation from Joyce's Finnegans Wake. It seems to me that the main character, Tristram St Lawrence, is named after Laurence Sterne and his Tristram Shandy. How have the Irish classics influenced your work and particularly your last novel? 
CK: Tristram Shandy isn't considered Irish.

\begin{abstract}
ALG: Isn't it?
CK: No... I studied it but I would have thought Laurence Sterne is British. I actually don't like Tristram Shandy. I am a classicist. As a writer I like the Greek paradigm of a prologue, an epilogue - the narrative arc. How have I been influenced by the classics? Every Irish writer has been influenced by Joyce. There is something for everyone in Joyce. I was talking about him earlier - the states of mind, the tenderness, the empathy. It's almost a given that every Irish writer will say "yeah, Joyce", but the main writer who I feel myself influenced by is [John] Banville. There was a chain: Banville was influenced by Nabokov, Nabokov was influenced by Joyce... but Banville is the Irish writer that I have. Certainly in my first book I was hugely influenced by him. What it is that draws me is the attempt to define states of mind, atmosphere, and place... It's the basic endeavour of trying to describe the human condition. Banville is funny - I think most Irish writers are funny, you know, there is a real humour in Irish life, that's how we do business with each other, with humour. Also, the way he evokes light is extraordinary - he writes so visually. I learned to write by reading him and Nabokov, and they are both funny, visual and emotional. So yeah, I would have to go back to Banville.
\end{abstract}

ALG: Your novel The Devil I Know is plenty of technical vocabulary on property development and various references to real facts, such as those Taoiseach Bertie Ahern's insensitive comments. How did you collect information about the boom for the writing of this book?

CK: Some of it is documentary and there was also the development in Howth. The site in Howth by the sea is a real site; I just transcribed the planning application. I did use a lot of actual quotes from many politicians and we have had politicians going to jail, so there is a lot of stuff lifted from the public discourse. Bertie Ahern got a quote, ["People who engaged in cribbing and moaning from the sidelines should frankly go and commit suicide, the Taoiseach had told us".]; Mary Harney got a quote ["The country is awash with money".]... If I went through it, I would find a lot of quotes from our leaders to the Irish people telling us how to behave during this period. The other thing is that you almost didn't have to research it because it was such a powerful ideology that was on every news show; it was on every newspaper, you couldn't escape it. So I didn't have to research it in the way I've had to actively research Tenderwire, my other novel set in the world of classical music, and All Summer, where there's a painting in it. I did not have to actively research it because it's stuff every Irish person who was an adult during this period would be familiar with.

ALG: Today everybody knows how the Irish property boom came to an end. References to the devil and hell are repeated throughout the narration and they are motifs that identify the crash with an inescapable condemnation for the financial sinners. But these references are also proleptic clues that predict how the conclusion of the story will be. Did you use this narrative device consciously?

CK: I knew it was going to be Faustian in November 2010. I realised how black and weird the train we were in was and the Faustian myth really fitted it. The idea that during the Celtic Tiger we sold our soul for a trifle, for property, for stuff... It was meaningless stuff, but it was expensive stuff. I finished the book in 2012 and it was set in 2016. Actually I didn't prophecy 
correctly because it's nearly 2016 now and things are better, thank God. When you are writing, you don't know what the end will be. I finished the last novel in May 2008 and I began this novel in July 2008, and I did not know what the ending would be; you just know that you want to write about these times, but you don't know how to turn it into a story. Things came very gradually. It started being narrated in Hickey's voice, the builder, and then Tristram came into it. I did not know he was an alcoholic.

I can't remember how M. Deauville came into it and who he was. I was once having a conversation on the phone with someone and I suspected that what was being said to me was being dictated by an AA [Alcoholics Anonymous] sponsor. In a situation like that, you are not actually talking to the people you think you are talking to; you are talking to their sponsor, who is brainwashing them. Thinking that is so creepy. That conversation happened in November 2008. That means that M. Deauville was there from the beginning. He was an early person, but I did not know who he was and that he would turn out to be the Devil. He wasn't called M. Deauville, he had another name and he was dictating everything. As we tumbled into oblivion in the wake of the crash, there was all these endeavours to sell Government Bonds, but then the market didn't respond well, so the Government had to withdraw the bonds, but then the market didn't like that either... I wondered who this market was. What was that force that Ireland was trying to appease and failing to appease and terrified of? Show me a face! So M. Deauville, or whatever he was called before I had a name for him, represented the financial markets, which had no country of origin, which is why he speaks any language. The financial markets are a very black force and, what is the blackest force? The Devil. It was 2010 or 2011 before I put an identity on M. Deauville, so it is only from then that I backtracked with clues that Tristram was actually dead when he sold his soul a long time ago to get back his life.

ALG: The very first narrative prolepsis of any book might be its title. Where does the title of your novel come from? It appears to be a line from a riddle or a popular saying...

CK: Do you not know the phrase "it's better the devil you know"? It's the phrase which means do not jump into the unknown - if you are in a bad marriage, your spouse is the devil you know. You might leave it and end up in a worse situation. It's a well known phrase.

\section{ALG: There is a similar proverb in Spanish...}

CK: I don't think it's my greatest title. My first novel is entitled All Names Have Been Changed - I got that title the day before the final draft, and I really like that title, but The Devil I Know... I'm sure there is a better title for this book.

ALG: I think your novel encompasses characteristics of Magic Realism. I find lots of similarities between the stories of Mexican Juan Rulfo's Pedro Páramo and The Devil I Know. You know this novel, don't you?

CK: No, do you recommend it?

ALG: Yes, you must read it. It was the favourite novel of Gabriel García Márquez. Were you aware of this style when writing the novel? Have you read any novel of this style before?

CK: Certainly Magic Realism is familiar, both the South American brand and the Angela Carter brand. To me this is more the Faustian myth, we are into German stuff now... 
ALG: Turning now to the main characters in your novel The Devil I Know. I think Tristram and Hickey perform a perfect duet allegory of different attitudes towards the property boom. On the one hand, Hickey is an illiterate, brutish working-class crook who wants to become rich overnight. On the other hand, Tristram is not accountable for his sins as he is being driven by an external force. He seems to be irresponsibly playing the role of victim rather than that of victimiser. Do you think these characters represent two kinds of social behaviour during the Celtic Tiger?

CK: I do, because actually there were not that many builders. I mean, if you line them all up, they don't fit in this room, I would say. But who let them do this? We let them do this, the rest of us, because it suited us. Tristram, because of his aristocratic background, is not the typical Irishman. Tristram was weak, useless and didn't stand up against this banditry. Yes, it was banditry that was going on with the builders; not all of them, but there were people who made a lot of money out of buildings that are not safe. So, Tristram isn't a criminal in the same way that Hickey and builders like him are. I think that reflected a lot of the mindset of the time, which was: "we are getting money here, just go with it." But then we got to the punishment, and Tristram was punished a lot worse than the builders, which is actually how it panned out with Irish society. The builders have done ok, whereas the ordinary people haven't done ok. Tristram is not your ordinary man, but he is the one who really paid with his soul.

The role of victim became the one that everyone claimed to play in the wake of this. During the Celtic Tiger people - the builders and bankers - claimed to play the role of the hero. They went very quiet obviously in the wake of the bust, but the role of victim is one that everyone was screaming to play. There were a lot of auditions for that role. I remember an Irish historian saying that a lot of Irish people did quite well out of the Famine, which is, if you didn't die or emigrate, because you got what was left. So the dust has not settled; it's too early to say how Irish society has been reorganised but it has been reorganised both socially but also the mindset. It's been such an extraordinary period of change and quite fast. From a country that was very poor for over 800 years to be really rich and then really poor with a big debt, that's going to take years to reflect upon, so I think there is going to be more writing about this era. It's not just Ireland anymore, it's Greece. Europe isn't looking too hot. The problem is really about finance.

\section{ALG: The spelling of the writing contrasts Hickey's Hiberno English dialect with Tristram's speech. By using this device, what do you want to highlight?}

CK: First of all, Hickey's lack of education. I also wanted to emphasise his own invented method of doing business. Bulldozing is the verb I've used to describe him. His street argot is pragmatic and rhythmic. I find it really funny. I had a very clear type in my head when I wrote that and his speech patterns. It's just so gung-ho. It's just: "I'm going to do this and I'm going to do it now, I'm not going to think, I'm not going to get my grammar right, I'm just going to mill in there and get what I want".

I find it funny and dangerous and I wanted to capture that. If someone couldn't be bothered speaking the language properly, they don't pay heed to anything. It's not just about language rules; it's about the rules of the Irish State, the rules of neighbourliness. And yet there is a great charm. He is an inventive man and he uses an inventive dialect. And he is very disrespectful to authority. Actually, that's what he is - it's a two-fingers-up to people like Tristram, who do speak well and who are educated and mindful of this stuff... It's a "fuck off' language what he speaks. 
ALG: Property development is depicted as a male-dominant space and, by words of a character, is a "matter of balls". The three female characters in the story are secondary and play gender roles - the nurturing mother, the caring nanny, and the wife. Do you think your novel reflects the hyper-masculinisation of Ireland during the Celtic Tiger period?

CK: I do. It just shows that genders don't work well without each other, they really don't. I don't like any of the women in this book. That's a weird thing for a woman to say. I actually like the men more even though they are the worst. They cause the damage but the women go with it because of personal gain. The only woman who I think is a good force is dead and that is Tristram's mother, who really cared for him. And I think part of his problem is his motherlessness. Since I became a mother in 2012 it has become really interesting to me what role a mother plays in mothering adults. Someone needs to care for you and have a value system that isn't about money.

Maybe Ireland has been motherless during this time. It just seemed very brash, very masculine, very macho, very harsh and not very maternal at all. In my own work, I'm moving away to the maternal world out of this. Dessie [Hickey] has a wife who is the mother to his, Christ, like 400 children. He has a lot of kids, none of them by his present wife. He goes back to her at the end of the novel, where he should never have left because she is a caring woman who has reared these children. So there is hope because he goes back to the mother of his children who loved him and got away from Edel, who was the "trophy-wife".

ALG: The end of the story is set in the preparations for the celebration of the Centenary of the Easter Rising. At this point, Tristram claims: 'One hundred years since the Proclamation [of the Irish Republic] and our sovereignty had been hocked'. Do Irish people need another independence proclamation? If so, why?

CK: Well, first of all, we are going to become familiar with the Proclamation now in a way that we weren't in the past. One of the parts of it was: the Nation cherishes all of its children equally. It is a big military endeavour, but now there is more emphasis on the female role during the Easter Rising in 1916, and to put that into the declaration of Independence (i.e. the Nation cherishes all of its children equally) is very beautiful, very "un-Irish", in terms of Catholic Ireland, where the Nation cherished some of the children born within wedlock but despised those born out of wedlock and their mothers. The Catholic stance that defines the Irishness we have now is about the sanctity of marriage and children. If we could keep the bit about cherishing all of the children equally in mind, that would be amazing. We live in a weird country and I did not understand the weirdness of Ireland until I had a baby and entered a hospital and was told I had to rely on the Blessed Mother. I didn't understand Ireland was still so mired in Catholicism. If we can change things like having to baptise your child to educate him in 2016, that would be great.

We have our sovereignty back and we have talked long and hard about it. There was a big conversation. Some people would jokingly say we should give the country back to the British, because they knew how to run it. It was a joke, but at the same time we are a people unable to run our own country. That was the lesson we learnt, and with that knowledge, maturity should grow out of that crisis. The Centenary is going to be interesting.

\section{ALG: What are your new interests? What are you working on at the moment?}


I am currently, having had a baby in 2012, trying to write a novel about motherhood. I have already written a personal essay on the topic which details the difficulty of writing anything at all once you become a mother - I had no time to write anything for three and a half years. I realise that it will be another decade or so before I begin to get my writing life back, but in the meantime, in the two or so writing hours I get a day, I want to treat the subject as a serious literary topic, because it is the hardest and most daunting thing I have done in my life, but it has also opened my eyes to all these gossamer threads of emotion joining us. I myself have had to revalue that figure of the woman pushing the pram. Before becoming a mother, I am shocked to say that I would have looked on pushing a pram as a waste of an education, a cop out. Now I see that it can be a state of extreme emotional turmoil or joy. I am also very angry about how so much of parenting falls to the woman and that anger will be in my book, whenever I find the time to write it.

Received: 20 August 2016

Revised version accepted: 27 May 2017

\section{Note}

This interview is part of the project of a research grant ("Beca de Iniciación a la Investigación") financed by the Internal Research Plan of the University of Granada (2015), under the supervision of Dr Pilar Villar Argáiz.

Alberto Lozano García is an English as a Foreign Language teacher in secondary education in Andalusia. He has a bachelor's degree in English Studies from the University of Granada, and a master's degree in Teacher Training from the University of Seville. His main academic interests include Ireland-UK political relations, the post-Celtic Tiger cultural expressions, and the connections between both Irish and Spanish-language literary traditions.

albertolozgar11@gmail.com 